\title{
Melihat Tingkat Efisiensi Bus Di Indonesia Dengan Metode DEA
}

\author{
Oleh:
}

Atiqi Chollisni

Aminuddin

Sekolah Tinggi Ekonomi Syariah (STES) Islamic Village Tangerang Jl. Raya Islamic Kelapa Dua Tangerang 15810, Indonesia

\begin{abstract}
Absrak: Tingkat efisiensi Bank Umum Syariah (BUS) dan Bank Umum Konvensional (BUK) di Indonesia dengan mengambil studi kasus 5 BUS dan 5 BUK di Indonesia dengan total sampel 10 bank. Metode yang digunakan dalam penelitian ini adalah Multi Stage DEA. Tahap pertama mengukur tingkat efisiensi BUS dan BUK dengan menggunakan DEA. Tahap kedua membandingkan tingkat efisiensi BUS dengan BUK.

Hasil penghitungan DEA menunjukkan, efisiensi Variable Return to Scale (VRS) efisiensi BUS mencapai $100 \%$, sementara dari Constant Return to Scale (CRS) dan skala mengalami fluktuasi. Sementara BUK juga memiliki nilai rata-rata efisiensi yang fluktuatif selama periode amatan dari tiga bentuk efisiensi. Dari hasil penelitian ini efisiensi BUS relatif lebih baik secara CRS maupun VRS, tetapi secara skala BUK lebih stabil dan lebih efisien dibanding BUS.
\end{abstract}

Kata Kunci: Efisiensi, BUS \& BUK, Data Envelopment Analysis (DEA)

\section{Pendahuluan}

Saat ini bank menjadi salah satu kegiatan usaha yang memegang peranan penting dalam perekonomian di Negara kita. Bank juga merupakan salah satu produk jasa yang digunakan oleh masyarakat. Penghimpunan dana merupakan kegitan pokok bank. Keberhasilan bank dalam melakukan perhimpunan atau mobilisasi dana ini sangat dipengaruhi oleh beberapa faktor, yang di antaranya adalah kepercayaan masyarakat pada suatu bank, di mana kepercayaan ini sangat dipengaruhi oleh kinerja bank yang bersangkutan. Untuk itu, nasabah pun lebih selektif dalam memilih bank.

Setelah keluarnya UU No.7 Tahun 1992 (diubah dengan UU No. 10 Tahun 1998) tentang Perbankan, Perbankan di Indonesia terbagi menjadi 2 (dua) jenis, yaitu bank umum dan bank perkreditan rakyat. Kedua bank tersebut melaksanakan kegiatan secara konvensional dan syariah. Hal ini 
berarti Indonesia menganut sistem perbankan ganda (dual banking system).

Adapun perkembangan selanjutnya adalah dikeluarkannya fatwa tentang keharaman bunga bank oleh Majelis Ulama Indonesia (MUI) pada tahun 2003. Keluarnya fatwa ini memberikan kotribusi yang signifikan terhadap perkembangan industry perbankan syariah di Indonesia. Setelah itu dilanjutkan dengan terbitnya peraturan perundang-undangan, yaitu Undang-Undang No.21 Tahun 2008 yang mengatur operasional perbankan syariah di Indonesia dan diperbarui dengan terbitnya Peraturan Bank Indonesia (PBI) No.11/3/PBI/2009 yang memuat tentang prosedur dan aturan dalam mendirikan Kantor Cabang, yang berdampak pada perkembangan jumlah kantor layanan bank syariah tumbuh dengan pesat.

Jumlah bank yang melakukan kegiatan usaha berdasarkan prinsip syariah pada tahun 2014 bertambah seiring dengan beroperasinya sejumlah bank baru. Jumlah BUS tercatat tidak bertambah dari tahun sebelumnya yaitu tetap sebanyak 12 BUS, sedangkan jumlah UUS berkurang menjadi 22 UUS dengan ditutupnya UUS HSBC sebagai bagian dari konsolidasi global bank induknya.

Bertambahnya jumlah bank juga diikuti dengan penambahan jaringan kantor, yang pada periode laporan bertambah sebanyak 1.599 kantor. Dari jumlah itu, 209 kantor merupakan jaringan kantor baru dari BUS dan 1.390 untuk jaringan kantor baru BUK.

Semakin banyaknya jumlah Bank yang beroperasi di Indonesia dengan berbagai bentuk produk dan pelayanan yang diberikan dapat menimbulkan permasalahan di masyarakat. Permasalahan yang paling penting adalah bagaimana kualitas kinerja bank yang ada. Dengan kondisi seperti ini, maka penilaian efisiensi bank menjadi sangat penting, karena efisiensi merupakan gambaran kinerja suatu perusahaan sekaligus menjadi faktor yang harus diperhatikan bank untuk bertindak rasional dalam meminimumkan tingkat risiko yang dihadapi dalam kegiatan operasinya.

Efisiensi dapat dilihat dari dua macam, yaitu biaya (Cost efficiency) dan keuntungan (Profit efficiency). Adapun Profit efficiency dibedakan menjadi 2 yaitu standar profit efficiency dan alternative profit efficiency Indikator efisiensi dapat dilihat dengan memperhatikan besarnya rasio Beban Operasional Terhadap Pendapatan (BOPO) dan rasio Non Performing Financing ( NPF). Kinerja bank dapat dikatakan efisiensi apabila rasio BOPO dan NPF mengalami penurunan. Selain itu efisiensi juga dapat dilihat dengan memperhatikan pertumbuhan tingkat indikator kinerja bank seperti jumlah simpanan, pembiayaan dan total aktiva. 
Semakin tinggi indikator kerja bank menunjukkan semakin baik dan produktif bank dalam kegiatan operasinya.

Namun untuk mengukur efisiensi perbankan tidak hanya dapat dilakukan dengan melihat perbandingan kinerja perbankan dan rasio keuangan saja, melainkan ada dua macam pendekatan yaitu pendekatan Parametrik dan Non-parametrik. Adapun pendekatan Parametric dilakukan dengan 3 pendekatan yaitu: Thick Frontier Approach (TFA), Stochastic Frontier Approach (SFA), dan Distribution Free Approach (DFA), sedangkan pendekatan Non-parametrikmeliputi pendekatan Data Envelopment Analysis (DEA) dan Free Disposal Hull (FDH).

Adapun data yang digunakan pada penelitian ini menggunakan data keuangan BUS dan BUK di Indonesia. Kemudian dibagi menjadi variable input dan output, adapun variable output yang digunakan adalah Laba bersih dan volume pembiayaan, sementara variable inputyang digunakan adalah beban operasional dan modal yang dimiliki.

\section{Bank}

Menurut Undang-Undang RI Nomot 10 tahun 1998 tanggal 10 November 1998 tentang Perbankan, Bank adalah badan usaha yang menghimpun dana dari masyarakat dalam bentuk simpanan dan menyalurkannya kepada masyarakat dalam bentuk kredit dan atau bentuk-bentuk lainnya dalam rangka meningkatkan taraf hidup rakyat banyak.

Bank Konvesional adalah bank yang dalam aktivitasnya, baik penghimpunan dana maupun dalam rangka penyaluran dana, memberikan dan mengenakan imbalan berupa bunga atau sejumlah imbalan dan persentase tertentu dari dana untuk suatu periode tertentu. Persentase tertentu ini biasanya ditetapkan pertahun (Triandaru dan Santoso,2006:153).

\section{Pengertian Bank Syariah}

Bank Syariah pada dasarnya sama dengan bank umum, akan tetapi segala aktifitasnya didasarkan pada prinsip-prinsip syariat islam, yaitu lembaga keuangan yang usaha pokoknya memberikan kredit dan jasa-jasa lain dalam lalu lintas pembayaran serta peredaran uang yang beroperasi disesuaikan prinsip-prinsip syariah (Sudarsono,2008).

Bank Syariah adalah bank yang dalam aktivitasnya, baik penghimpunan dana maupun dalam rangka penyaluran dananya memberikan dan mengenakan imbalan atas dasar prinsip syariah yaitu jual beli dan bagi hasil (Triandaru dan Santoso,2006:153). Dimana 
terdapat pelarangan pengambilan bunga yang dalam syariat islam termasuk salah satu jenis riba yang dilarang syariat islam.

Antonio dan Perwatatmaja (1999:1 ), membedakan bank syariah menjadi dua pengertian, yaitu Bank Islam dan Bank yang beroperasi dengan prinsip syariah Islam. Bank Islam adalah (1) bank yang beropeasi sesuai dengan prinsip-prinsip syariah Islam; (2) Bank yang tata cara beroperasinya mengacu kepada ketentuan-ketentuan Al Quran dan Hadis. Sementara bank yang beroperasi sesuai prinsip syariah Islam adalah bank yang dalam beroperasinya itu mengikuti ketentuan-ketentuan syariah Islam, khususnya yang menyangkut tata cara bermuamalat secara Islam. Dalam tata cara bermuamalat ini menghindari praktek yang dikhawatirkan mengandung unsur riba dan diisi dengan kegiatankegiatan investasi atas dasar bagi hasil dan pembiayaan perdagangan.

Prinsip utama yang digunakan dalam kegiatan perbankan syariah adalah:

1. Larangan riba dalam berbagai bentuk transaksi.

2. Melakukan kegiatan usaha perdagangan berdasarkan perolehan keuntungan yang sah.

3. Memberikan zakat.

Oleh karena itu, dalam operasinya perbankan syariah tidak menerapkan sistem bunga seperti bank konvensional tetapi menerapkan sistem bagi hasil. Hal ini sesuai dengan fatwa MUI tanggal 16 Desember 2003 yang menggolongkan bunga bank termasuk riba, dan menurut $\mathrm{Al}-$ Qur`an riba adalah haram. Pernyataan ini ditegaskan oleh ayat-ayat dalam QS. Al Baqarah Ayat 275 - 279.

Riba itu ada dua macam yaitu riba nasiah dan riba fadhl. Riba Nasiah ialah pembayaran lebih yang disyaratkan oleh orang yang meminjamkan. Riba Fadhl ialah penukaran suatu barang dengan barang yang sejenis, tetapi lebih banyak jumlahnya Karena orang yang menukarkan mensyaratkan demikian, seperti penukaran emas dengan emas, padi dengan padi, dan sebagainya.

\section{Perbandingan Antara Bank Umum Syariah Dan Bank Umum Konvensional}

Untuk menghindari perbuatan yang dilarang dalam Al-Qur’an maupun Al-Hadits, maka bank-bank yang menganut prinsip syariah menerapkan prinsip bagi hasil yang sesuai dengan syariah. Dan inilah yang membedakan bank yang menganut prinsip syariah dengan bank konvensional yang telah ada selama ini. Dimana bank konvensional masih menerapkan bunga sebagai imbalan yang diterima oleh nasabahnya. Adapun perbadaan bunga dan bagi hasil dapat dijelaskan lebih jauh dalam tabel berikut: 
Perbandingan sistem bunga dan bagi hasil

\begin{tabular}{|l|l|l|}
\hline $\begin{array}{l}\text { Perbedaan antara } \\
\text { Sistem Bunga dan } \\
\text { Bagi Hasil }\end{array}$ & \multicolumn{1}{|c|}{ Sistem Bunga } & \multicolumn{1}{c|}{ Sistem Bagi Hasil } \\
\hline $\begin{array}{l}\text { Penentuan } \\
\text { besarnya hasil }\end{array}$ & Sebelumnya & $\begin{array}{l}\text { Sesudah berusaha, sesudah } \\
\text { ada untungnya }\end{array}$ \\
\hline Yang ditentukan & $\begin{array}{l}\text { Bunga, besarnya nilai } \\
\text { rupiah }\end{array}$ & $\begin{array}{l}\text { Menyepakati proporsi } \\
\text { pembagian untung untuk } \\
\text { masing-masing pihak, } \\
\text { misalnya 50:50, 40: 60, dst }\end{array}$ \\
\hline $\begin{array}{l}\text { Jika terjadi } \\
\text { kerugian }\end{array}$ & Ditanggung nasabah & $\begin{array}{l}\text { Ditanggung kedua belah } \\
\text { pihak, nasabah dan lembaga }\end{array}$ \\
\hline $\begin{array}{l}\text { Dihitung dari mana } \\
?\end{array}$ & $\begin{array}{l}\text { Dari dana yang } \\
\text { dipinjamkan, fixed, } \\
\text { tetap }\end{array}$ & $\begin{array}{l}\text { Dari untung yang bakal } \\
\text { diperoleh, belum tentu } \\
\text { besarnya }\end{array}$ \\
\hline $\begin{array}{l}\text { Titik perhatian } \\
\text { proyek/usaha }\end{array}$ & $\begin{array}{l}\text { Besarnya bunga yang } \\
\text { harus dibayar } \\
\text { nasabah/pasti } \\
\text { diterima bank }\end{array}$ & $\begin{array}{l}\text { Keberhasilan proyek/usaha } \\
\text { jadi perhatian bersama: } \\
\text { Nasabah dan Lembaga }\end{array}$ \\
\hline Berapa besarnya? & $\begin{array}{l}\text { Pasti: (\%) x jumlah } \\
\text { pinjaman yang telah } \\
\text { diketahui }\end{array}$ & $\begin{array}{l}\text { Proporsi: (\%) x jumlah } \\
\text { untung yang belum diketahui } \\
\text { = belum diketahui }\end{array}$ \\
\hline Status hukum & $\begin{array}{l}\text { Berlawanan dengan } \\
\text { QS. Luqman: 34 }\end{array}$ & $\begin{array}{l}\text { Melaksanakan QS. Luqman: } \\
\text { 34 }\end{array}$ \\
\hline
\end{tabular}

Sumber: Muhammad, 2004; 4

Sedangkan perbandingan antara bank konvesional dan bank yang menganut prinsip syariah adalah seperti terlihat pada tabel 2.2 berikut:

Perbandingan antara Bank Syariah dan Bank Konvensional

\begin{tabular}{|l|l|}
\hline \multicolumn{1}{|c|}{ Bank Syariah } & \multicolumn{1}{c|}{ Bank Konvensional } \\
\hline 1) Investasi yang halal & 1) Investasi halal dan haram \\
\hline 2) Prinsip bagi hasil, jual beli, atau sewa & $\begin{array}{l}\text { 2) Memakai perangkat } \\
\text { bunga }\end{array}$ \\
\hline 3) Profit dan falah oriented & 3) Profit oriented \\
\hline 4) Hubungan kemitraan & $\begin{array}{l}\text { 4) Hubungan debitor- } \\
\text { kreditor }\end{array}$ \\
\hline $\begin{array}{l}\text { 5) Penghimpunan dan penyaluran dana harus } \\
\text { sesuai dengan fatwa Dewan Pengawas } \\
\text { Syariah (DSN) }\end{array}$ & $\begin{array}{l}\text { 5) Tidak terdapat dewan } \\
\text { sejenis }\end{array}$ \\
\hline
\end{tabular}

Sumber: Antonio 2001; 34 
Dalam mengelola usahanya dalam perbankan syariah dikenal prinsipprinsip sebagai berikut (BI,2005):

1) Mudharabah adalah penanaman dana dari pemilik dana (shahibul maal) kepada pengelola dana (mudharib) untuk melakukan kegiatan usaha tertentu, dengan pembagian menggunakan metode bagi untung dan rugi (profit and loss sharing) atau metode bagi pendapatan (revenue sharing) antara kedua belah pihak berdasarkan nisbah yang telah disepakati sebelumnya.

2) Musyarakah adalah penanaman dana dari pemilik dana/modal untuk mencampurkan dana/modal mereka pada suatu usaha tertentu, dengan pembagian keuntungan berdasarkan nisbah yang telah disepakati sebelumnya, sedangkan kerugian ditanggung semua pemilik dana/modal berdasarkan pembagian dana/modal masingmasing.

3) Murabahah adalah jual beli barang sebesar harga pokok barang ditambah dengan tingkat keuntungan yang disepakati.

4) Ijarah adalah transaksi sewa menyewa atas suatu barang dan atau upah mengupah atas suatu jasa dalam waktu tertentu melalui pembayaran sewa atau imbalan jasa.

5) Ijarah Wa Iqtina adalah penitipan dana atau barang dari pemilik dana atau barang pada penyimpan dana atau barang dengan kewajiban pihak yang menerima titipan untuk mengembalikan dana atau barang titipan sewaktu-waktu.

6) Salam adalah jual beli barang dengan cara pemesanan dengan syaratsyarat tertentu dan pembayaran tunai terlebih dahulu secara penuh.

7) Istisha'adalah jual beli barang dalam bentuk pemesanan pembuatan barang dengan kriteria dan persyaratan tertentu yang disepakati dengan pembayaran sesuai dengan kesepakatan.

8) Qardadalah pinjam meminjam dana tanpa imbalan dengan kewajiban pihak peminjam mengembalikan pokok pinjaman secara sekaligus atau cicilan dalam jangka waktu tertentu.

\section{Bentuk Hukum}

Bentuk badan hukum lembaga yang melakukan kegiatan usaha berdasarkan prinsip syariah dapat berupa:

1. Perseroan Terbatas (PT)

2. Koperasi

3. Perusahaan Daerah 


\section{Landasan Hukum}

a) Undang-Undang Republik Indonesia Nomor 7 Tahun 1992 tentang Perbankan yang telah diamandemen dengan UndangUndang Nomor 10 Tahun 1998.

b) Undang-Undang Republik Indonesia Nomor 23 Tahun 1999 tentang Bank Indonesia yang telah diamandemen dengan Undang-Undang Republik Indonesia Nomor 3 Tahun 2004.

\section{Konsep Efisiensi}

Efisiensi merupakan salah satu parameter kinerja yang secara teoritis merupakan salah satu kinerja yang mendasari seluruh kinerja UPK. Kemampuan menghasilkan outputyang maksimal dengan input yang ada adalah ukuran kinerja yang diharapkan. Pada saat pengukuran efisiensi dilakukan, UPK dihadapkan pada kondisi bagaimana mendapatkan tingkat output yang optimal dengan tingkat input yang ada, atau mendapatkan tingkat output tertentu atau tetap dengan tingkat input yang minimum. Di samping itu, dengan adanya pemisahan antara unit dan harga, dapat diidentifikasi beberapa tingkat efisiensi tekhnologi, efisiensi alokasi input dan output, dan melihat penyebab ketidakefisienan (Prasetyo, 2007).

Efisiensi dalam konsep ekonomi merujuk pada sejumlah konsep yang terkait pada penggunaan, pemaksimalan serta pemanfaatan seluruh sumber daya dalam proses produksi barang dan jasa (Dalam Wikipedia berbahasa Indonesia, 2003). Penggunaan sumber-sumber daya bisa dikatakan efisien apabila: (1) Seluruh sumber-sumber daya yang tersedia sepenuhnya digunakan; (2) Corak penggunaannya adalah sudah sedemikian rupa sehingga tidak terdapat lagi corak penggunaan lain yang akan memberikan tambahan kemakmuran bagi masyarakat/individu.

Sementara itu, di dalam proses produksi, efisiensi dapat dibedakan menjadi dua macam, yaitu efisiensi produktif dan efisiensi alokatif.

a) Efisiensi produktif, adalah menilai efisiensi di dalam tahapan produksi. Penilaian efisiensi produktif dapat dilihat dari sisi biaya. Untuk mencapai efisiensi produktif ini harus dipenuhi dua syarat. Pertama, untuk setiap tingkat produksi, biaya yang dikeluarkan adalah yang paling minimum. Kedua, perusahaan atau industri secara keseluruhan harus memproduksikan barang pada biaya rata-rata yang paling rendah.

b) Sedangkan efisiensi alokatif, menilai efisiensi secara teknis di dalam proses produksi, yakni dari segi pengalokasiaan sumbersumber daya yang tersedia. Efisiensi alokatif akan tercapai ketika alokasi sumber-sumber daya tersebut ke berbagai kegiatan 
ekonomi/produksi telah mencapai tingkat yang maksimum/optimum.

\section{Efisiensi Dengan Pendekatan Parametrik dan Nonparametrik}

Dalam pengukuran efisiensi, ada dua pendekatan yang digunakan, yaitu pendekatan parametrik dan nonparametric (Mansyrur,2012):

a. Pendekatan Nonparametrik

Pendekatan noparametrik menggunakan program linear dengan pendekatan yang tidak stokastik dan cenderung mengkombinasikan gangguan dan ketidak efisienan.

1. Data Envelopment Analysis (DEA)

DEA adalah metode nonparametrik yang menggunakan model program linier untuk menghitung perbandingan rasio output dan input untuk semua unit yang diperbandingkan. Keuntungan dari penggunaan DEA ini adalah bahwa pendekatan ini tidak memerlukan spesifikasi yang eksplisit dari bentuk fungsi dan hanya memerlukan sedikit struktur untuk membentuk frontier efisiensinya. Kelemahan yang mungkin muncul adalah self identifier dan near self identifier.

2. Free Disposal Hull(FDH)

Metode ini merupakan generalisasi dari DEA dengan model variable return to scale. Metode ini tidak mensyaratkan estimasi frontieryang berbentuk cembung (convex).

b. Pendekatan Parametrik

Pendekatan parametrik melakukan pengukuran dengan menggunakan ekonometrik yang stokastik dan berusaha untuk menghilangkan gangguan dari ketidakefisienan.

1. Stocastic Frontier Approach (SFA)

Merupakan metode ekonometrik yang mengasumsikan efisiensi mengikuti distribusi asimetrik, biasanya setengah normal (half normal), sementara random error diasumsikan mengikuti distribusi standar simetrik.

2. Thick Frontier Approach (TFA)

Model yang dikembangkan oleh Berger dan Humprey (1991) ini membandingkan rata-rata efisiensi dari kelompok perusahaan dan bukannya mengestimasi frontier.

3. Distribution Free Approach (DFA)

Model ini menggunakan residual rata-rata dari fungsi biaya yang diestimasi pada panel data untuk membangun suatu 
ukuran cost standard efficiency. Metode ini tidak memaksakan suatu bentuk spesifik pada distribusi dari efisiensi rata-rata untuk setiap perusahaan yang besarnya konstan dari waktu ke waktu.

\section{Konsep Efisiensi Bank}

Perbankan sebagai salah satu lembaga keuangan yang memiliki peranan penting dituntut untuk memiliki kinerja yang baik. Salah satu indikatornya adalah efisiensi. Tingkat efisiensi yang dicapai merupakan cerminan dari kualitas kinerja yang baik. Kemampuan menghasilkan outputyang maksimal dengan input yang ada, adalah merupakan ukuran kinerja yang diharapkan.

Menurut Hadad (2003), pada saat pengukuran efisiensi dilakukan, bank dihadapkan pada kondisi bagaimana mendapatkan tingkat output yang optimal dengan tingkat input yang ada, atau mendapatkan tingkat input yang minimum dengan tingkat output tertentu.

Priyonggo (2008; 35), memandang efisiensi perbankan dapat dilihat dari dua sisi, yaitu dari sisi biaya (cost efficiency) dan dari sisi keuntungan (profit efficiency). Dilihat dari sisi biaya (cost efficiency), sebuah bank dinilai dengan dibandingkan dengan bank yang memiliki biaya beroperasi terbaik (best practice bank's cost) yang menghasilkan output yang sama dan teknologi yang sama. Sementara dari sisi keuntungan (profit efficiency), mengukur tingkat efisiensi dari kemampuan sebuah bank dalam menghasilkan laba/keuntungan pada setiap unit input yang digunakan.

\section{Efisiensi Dalam Islam}

Tujuan efisiensi adalah untuk mendapatkan pemasukan yang maksimal dengan pengeluaran yang minimal. Dalam Islam lebih menekankan keseimbangan, yaitu untuk mendapatkan hasil yang maksimal harus dengan usaha yang maksimal begitu juga dengan sebaliknya. Menekan biaya yang sebesar-besarnya untuk mendapatkan keuntungan yang paling maksimal dalam teori produsen akan berakibat pada perbuatan dzalim yang tidak bersenyawa dengan ruh Islam. Dalam Islam, perwujudan keuntungan yang optimal dihasilkan melalui usaha yang optimal (kerja keras) untuk menghasilkan sesuatu secara optimal dengan tetap menjaga keseimbangan (ta'adul) dan etika syariah. Keuntungan yang dihasilkan harus seimbang dengan kerja keras dan beban yang dikeluarkan. Kaidah ini didasari oleh sabda Rasulullah saw, Al-Kharaj bid-Dhaman (Hak mendapatkan hasil itu disebabkan oleh keharusan menanggung kerugian). Keseimbangan juga berarti bahwa 
dalam mewujudkan value added, produsen perlu memperhatikan aspek sosial, ekonomi, dan lingkungan.

Untuk mewujudkan optimalisasi dan keseimbangan, Islam memberikan beberapa petunjuk, di antaranya:

a. Memanfaatkan seluruh potensi sumber daya alam. Islam menghendaki umatnya untuk bekerja memakmurkan bumi dan memanfaatkan seluruh potensi sumber daya alam. Allah berfirman dalam QS. Huud Ayat 61

b. Spesialisasi kerja. Spesialisasi kerja diartikan sebagai memberikan tugas tertentu kepada orang tertentu yang memiliki kualifikasi tertentu. Tujuan dari adanya spesialisasi kerja adalah untuk menghasilkan tingkat output yang lebih besar dengan sejumlah input yang sama melalui peningkatan produktifitas. Dalam Islam, prinsip dasar tentang spesialisasi dapat ditelaah dalam hadits Nabi saw yang menjelaskan tentang konsep itqan dan ihsan. Mengenai itqan, Rasulullah saw bersabda: "Sesungguhnya Allah mencintai jika seseorang melakukan pekerjaan (berproduksi) dengan cermat dan tekun (itqan)" (HR. Thabrani).

\section{Metode}

Pada penelitian dengan metode Data Envelopment Analysis (DEA) ini, variabel input dan output yang digunakan adalah sebagai berikut :

a. Variabel output (Y) : Laba bersih, Pembiayaan.

b. Variabel input (X) : Modal, Biaya Operasional.

Metode analisis efisiensi menggunakan DEA membutuhkan data yang berupa input dan output suatu Unit Kegiatan Ekonomi (UKE). Variabel output yang digunakan pada penelitian ini adalah: Modal dan Biaya Operasional.

a. Modal. Modal bank terdiri atas modal inti (primary capital) yang komponennya terdiri atas modal disetor dan cadangancadangan yang dibentuk dari laba setelah pajak. Modal juga terdiri dari modal pelengkap (secondary capital) yang terdiri atas cadangan yang tidak dibentuk dari laba setelah pajak dan pinjaman yang dapat disamakan dengan modal secara rinci.

b. Biaya Operasional. Biaya Operasional merupakan biaya bunga, biaya bagi hasil, biaya valuta asing, biaya overhead, biaya pegawai, biaya kegiatan kantor dan biaya penyusutan.

Sedangkan untuk beberapa definisi variabel dari input yang digunakan pada penelitian ini yaitu: Laba dan pendapatan operasional.

a. Laba bersih. 
Laba bersih merupakan selisih antara jumlah keseluruhan pendapatan dan jumlah keseluruhan biaya dalam jangka waktu tertentu. Laba bersih merupakan elemen paling menjadi perhatian, karena angka laba diharapkan cukup untuk merepresentasikan perusahaan keseluruhan.

b. Pembiayaan

Pembiayaan adalah penyediaan uang atau tagihan yang dipersamakan dengan itu berdasarkan persetujuan atau kesepakatan antara bank dengan pihak lain yang mewajibkan pihak yang dibiayai untuk mengembalikan uang atau tagihan tersebut setelah jangka waktu tertentu dengan imbalan atau bagi hasil (UU No.10 Pasal 1 Ayat 12). Pembiayaa merupakan pos dengan porsi terbesar yang dikeluarkan oleh bank, karena operasional bank dapat berjalan dipengaruhi oleh tingkat pembiayaan bank.

\section{Populasi dan Sampel}

Sampel penelitian ini adalah bank-bank di Indonesia, baik Bank Umum Syariah (BUS) maupun Bank Umum Konvensional (BUK) dan tidak termasuk BPRS dan BPR Konvensional pada periode 2012 sampai 2014 sebanyak 10 bank, masing-masing terdiri dari 5 BUS dan 5 BUK.

Pengambilan sampel dalam penelitian ini dilakukan secara purposive sampling artinya metode pemilihan sampel dipilih berdasarkan pertimbangan (judgement sampling) yang berarti pemilihan sampel secara tidak acak yang informasinya diperoleh dengan pertimbangan tertentu. Sampel dalam penelitian ini diambil berdasarkan kriteria sebagai berikut.

1. BUS dan UUS yang beroprasi di Indonesia selama periode pengamatan 2012-2014.

2. Secara konsisten tidak mengalami perubahan bentuk badan usaha pada periode pengamatan 2012-2014.

3. Menyajikan laporan keuangan pada periode pengamatan 20122014 dan telah dipublikasikan di Bank Indonesia.

\section{Metode Data Envelopment Analysis (DEA)}

Teknik analisis yang digunakan dalam penelitian ini yaitu DEA (Data Envelopment Analysis) dengan pendekatan intermediasi. Pendekatan intermediasi ini memandang sebuah lembaga keuangan sebagai intermediator, yaitu merubah dan mentransfer aset-aset financial dari unit-unit surplus menjual unit-unit defisit. Dalam hal ini output yang 
diukur dalam bentuk laba bersih dan Pembiayaan, lalu dengan input yaitu modal dan Biaya Operasional.

\section{Model Pengukuran Efisiensi Teknik Bank}

Efisiensi teknik perbankan diukur dengan menghitung rasio antara output dan inputnya. DEA akan menghitung bank yang menggunakan input $n$ untuk menghasilkan output $m$ yang berbeda (Miller dan Noulas, 1996). Efisiensi bank diukur sebagai berikut :

$$
h_{s}=\sum_{i=1}^{m} u_{i} y_{i s} / \sum_{j=1}^{n} V_{j} X_{j s}
$$

dimana:

hs adalah efisiensi teknik bank s

yis merupakan jumlah output iyang diproduksi oleh bank s.

xjs adalah jumlah input j yang digunakan oleh bank $\mathrm{s}$

ui merupakan bobot output i yang di hasilkan oleh bank $s$

$v j$ adalah bobot input j yang diberikan oleh bank $s$, dan $i$ dihitung dari 1 ke $m$ serta $j$ dihitung dari 1 ke $n$.

Persamaan 3.1 diatas menunjukkan adanya penggunaan satu variabel input dan satu output. Rasio efisiensi $(h s)$, kemudian dimaksimalkan dengan kendala sebagai berikut:

$$
\sum_{\substack{i=1 \\ \mathrm{U}_{\mathrm{i}} \operatorname{dan} V_{j} \geq 0}}^{m} u_{i} y_{i r} / \sum_{j=1}^{n} V_{j} X_{j r} \leq 1 \text { untuk } \mathrm{r}=1, \ldots . \mathrm{N}
$$

Dimana $\mathrm{N}$ menunjukkan jumlah bank dalam sampel. Pertidaksamaan pertama menunjukkan adanya efisiensi rasio untuk UKE lain tidak lebih dari 1, sementara pertidaksamaan kedua berbobot positif. Angka rasio akan bervariasi antara 0 sampai dengan 1 . Bank dikatakan efisien apabila memiliki angka rasio mendekati 1 atau 100 persen, sebaliknya jika mendekati angka 0 menunjukkan efisiensi bank yang semakin rendah. Pada DEA, setiap bank dapat menentukan pembobotnya masing-masing dan menjamin bahwa pembobot yang dipilih akan menghasilkan ukuran kinerja yang terbaik (Sutawijaya dan Lestari, 2009).

Model pengukuran teknik bank berdasarkan asumsi pendekatan frontier dibagi menjadi dua jenis, yaitu :

a. Model DEA CCR (Charnes-Cooper-Rhodes, 1978) 
Asumsi yang digunakan dalam model ini adalah Constan Return to Scale (CRS). Beberapa program linier ditransformasikan ke dalam program ordinary liniear secara primal atau dual, sebagai berikut:

$h_{s}=\sum_{i=1}^{m} u_{i} y_{i s}$

Maksimisasi

(3.3)

$\sum_{i=1}^{m} u_{i} y_{i r}-\sum_{j=1}^{n} V_{j} X_{j r} \leq 0, \mathrm{r}=1, \ldots \mathrm{N}$;

Kendala

(3.4)

$\sum_{j=1}^{m} V_{J} y_{j s}=1$

Dan $U_{i}$ dan $V_{j} \geq 0$

Efisiensi pada masing-masing bank dihitung menggunakan programasi linier dengan memaksimumkan jumlah output yang dibobot dari bank $s$. Kendala jumlah input yang dibobot harus sama dengan satu untuk bank $s$, sedangkan kendala untuk semua bank yaitu output yang dibobot dikurangi jumlah input yang dibobot harus kurang atau sama dengan 0. Hal ini berarti bahwa semua bank akan berada atau di bawah referensi kinerja frontier yang merupakan garis lurus yang memotong sumbu origin (Insukirdo, dkk, 2000:20)

c. Model DEA BCC (Bankers, Charnes dan Cooper, 1984).

Asumsi yang digunakan dalam model ini adalah Variable Return to Scale (VRS). Beberapa program linier ditransformasikan ke dalam program ordinary liniear secara primal atau dual, sebagai berikut:

$h_{s}=\sum_{i=1}^{m} u_{i} y_{i s}+U_{\mathrm{o}}$

Maksimisasi

$\sum_{i=1}^{n} u_{i} y_{i r}-\sum_{j=1}^{m} V_{j} X_{j r} \leq 0, \mathrm{r}=1, \ldots \mathrm{N}$;

Kendala 


$$
\begin{aligned}
& \sum_{j=1}^{n} V_{J} X_{j s}=1 \\
& \operatorname{Dan} U_{i} \operatorname{dan} V_{j} \geq 0
\end{aligned}
$$

di mana Uo merupakan penggal yang dapat bernilai positif atau negatif.

Seperti yang telah dikemukakan diatas, bahwa terdapat dua model DEA yang sering digunakan untuk mengukur efisiensi, yaitu CCR dan BCC. Charnes, Cooper dan Rhodes (1978) mengembangkan model DEA dengan metode constant return to scale (CRS) dan selanjutnya dikembangkan oleh Banker, Charnes dan Cooper dengan metode variable return to scale (VRS) yang akhirnya terkenal dengan model CCR (Charnes-Cooper-Rhodes) dan BCC (Banker- CharnesCooper) (Amrillah, 2010).

CCR mengasumsikan adanya CRS. Yang dimaksud dengan asumsi CRS adalah bahwa perubahan proporsional pada semua tingkat input akan menghasilkan perubahan proporsional yang sama pada tingkat output. Sedangkan BCC mengasumsikan adanya VRS. Yang dimaksud dengan asumsi VRS adalah bahwa semua unit yang diukur akan menghasilkan perubahan pada berbagai tingkat output dan adanya anggapan bahwa skala produksi dapat mempengaruhi efisiensi. Dalam penelitian ini hanya akan menggunakan pendekatan output orientation dengan asumsi CRS, karena dengan pendekatan output orientation kita dapat melihat seberapa besar output yang akan dihasilkan dengan jumlah input yang sama antara UKE.

\section{Tingkat Efisiensi Bank Umum Syariah}

Hasil pengolahan DEA juga menunjukkan bahwa dari 5 Bank Umum Syariah yang diteliti, ada 3 bank yang relatif efisien pada tahun 2012, yaitu Bank Syariah Mandiri, Bank Muamalat Indonesia dan Bank Mega Syariah. Sedangkan untuk Bank BNI Syariah dan Bank BRI Syariah belum menunjukkan pencapaian tingkat efisiensi, bahkan bank BNI Syariah menunjukkan tingkat efisiensi paling rendah, yaitu 0,535 secara Constant return to scale (CRS) dan skala. Tahun 2013, masih sama seperti tahun sebelumnya, bank yang mencapai tingkat efisiensi maksimum dan yang masih belum mencapai tingkat efisien secara CRS dan Skala, namun sudah menunjukkan kenaikan. Pada tahun 2014, terdapat 1 bank yang konsisten dengan nilai efisiensi optimal baik secara Constant return to scale (CRS), teknis maupun skala, yaitu Bank Muamalat Indonesia. Sementara Bank BNI Syariah dan Bank BRI Syariah berhasil mencapai tingkat efisiensi 
$100 \%$ di semua bidang, ini menunjukkan bahwa kedua bank ini terus mengalami kenaikan. Sedangkan untuk Bank Syariah Mandiri dan Bank Mega Syariah justru mengalami penurunan tingkat efisiensi, padahal pada tahun-tahun sebelumnya tingkat efisiensinya mencapai 100\%, untuk BSM ini dipengaruhi minimnya tingkat laba bersih dan tingginya biaya operasional sehingga mengalami penurunan tingkat efisiensi. Sedangkan untuk Bank Mega Syariah dipengaruhi menurunnya tingkat pembiayaan sehingga berdampak pada penurunan laba bersih.

\section{Tingkat Efisiensi Bank Umum Konvensional}

Adapun Bank Umum Konvensional, dari 5 bank yang diteliti pada periode 2012-14, 3 bank telah beroperasi secara efisien dengan skor efisiensi $100 \%$ baik secara CRS, VRS, maupun skala. Ketiga bank tersebut adalah Bank Rakyat Indonesia (BRI), Bank BCA dan Bank Tabungan Negara (BTN). Sementara pada tahun 2012 dan 2013, Bank Mandri menunjukkan tingkat efisiensi 100\% secara VRS tetapi tidak secara CRS maupun skala. Sedangkan pada tahun 2014 Bank Mandiri belum mencapai tingkat efisiensi baik secara CRS, VRS, maupun skala, tetapi terus menunjukkan kenaikan tingkat efisiensinya. Adapun Bank Negara Indonesia (BNI) selama tahun amatan belum pernah mencapai tingkat efisiensi $100 \%$, baik secara CRS, VRS, maupun skala bahkan cenderung fluktuatif, mengalami kenaikan di tahun 2013 tapi kembali turun di tahun 2014 walaupun kenaikan dan penurunannya tidak telalu signifikan.

\section{Perbandingan Efisiensi BUS dan BUK}

Tingkat efisiensi BUS berdasarkan CRS cukup fluktuatif, pada tahun 2013 naik menjadi 96,6\% dari tahun sebelumnya yang hanya mencapai tingkat efisiensi 86,1\%, namun pada tahun 2014 kembali turun menjadi 91,6\%. Sedangkan untuk BUK, secara CRS juga mengalami pasang surut, namun tidak terlalu signifikan yaitu pada tahun 2012 tingkat efisiensi BUK mencapai 95,3\%, dan pada tahun 2013 naik menjadi 97,1\%, tetapi pada tahun 2014 kembali turun menjadi 94,2\%.

Selanjutnya secara VRS diketahui tingkat efisiensi BUS mencapai skor 1 atau 100\% selama periode 2012-2014, ini artinya secara VRS tingkat efisiensi BUS relatif lebih efisien dan konsisten dibandingkan tingkat efisiensi BUK yang pada periode pengamatan mengalami fluktuasi, pada tahun 2012 nilai efisiensinya 95\% selanjutnya naik menjadi $97 \%$ pada tahun 2013 dan kembali turun menjadi 94\% pada tahun 2014.

Untuk Skala efisiensi, tingkat efisiensi BUS sama persis seperti CRS, yaitu pada tahun 2012 tingkat efiensi BUS 86,1\%, lalu pada tahun 2013 naik menjadi $96,6 \%$ dan turun menjadi 91,6\% pada tahun 2014, sedangkan untuk BUK skala efisiensi menunjukkan trend yang positif, yaitu terus mengalami kenaikan pada periode amatan. Tahun 2012 hanya 
mencapai 95,3\%, tahun 2013 naik menjadi 96\% dan pada tahun 2014 kembali naik menjadi $98,3 \%$.

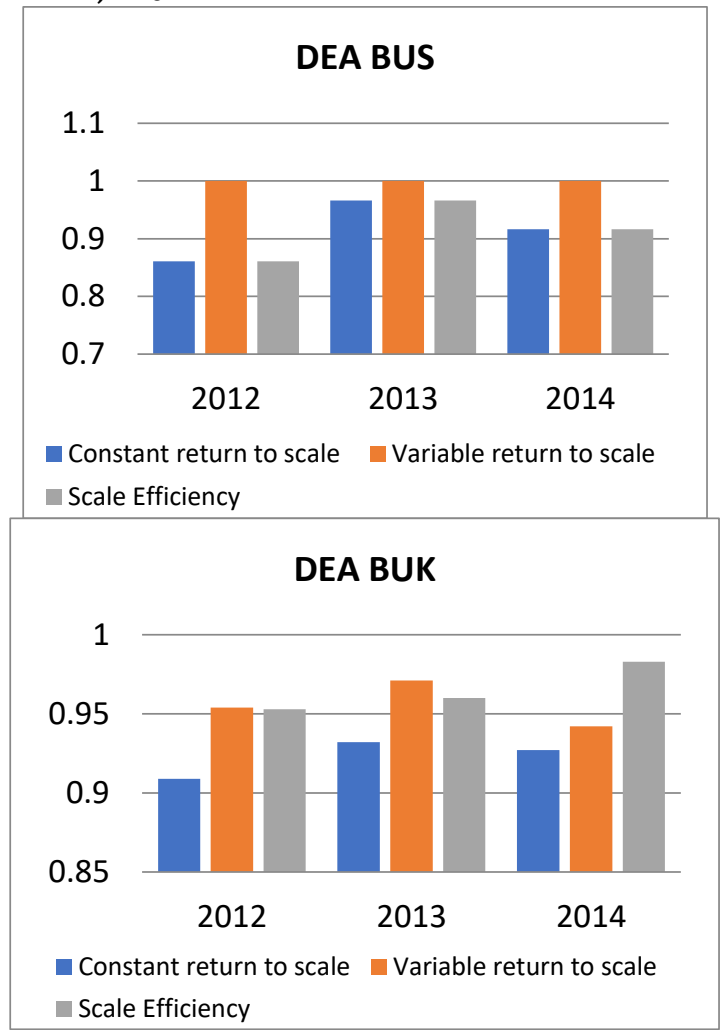

\section{Gambar 1}

\section{Efisiensi BUS \& BUK}

Dari uraian di atas dapat disimpulkan bahwa secara teknis, BUS relative lebih efisien disbanding BUK karena tingkat efisiensi BUS mencapai $100 \%$ selama masa periode 2012-2014, sementara dari segi VRS dan skala mengalami kenaikan pada tahun 2013, tetapi mengalami penurunan pada tahun 2014. Sementara BUK juga memiliki nilai rata-rata efisiensi yang fluktuatif selama periode amatan dari tiga bentuk efisiensi. Dari hasil pengolahan data juga dapat disimpulkan bahwa efisiensi BUS relatif lebih efisien selama periode 2012-2014, baik secara CRS maupun VRS, tetapi secara skala BUK lebih stabil dan lebih efisien disbanding BUS, karena menunjukkan tren positif di setiap tahunnya. Puncaknya pada tahun 2013, BUS memiliki tingkat efisiensi yang lebih tinggi disegala bidang dari BUK.

\section{Potensi Perbaikan Per-Bank}

Dengan pendekatan Variable return to scale (VRS) dapat diketahui potensi perbaikan tiap bank, yang mana terdapat angka aktual dan angka 
target, angka aktual adalah angka yang dimiliki input output sedangkan angka target adalah angka yang disarankan penghitungan DEA untuk mencapai efisiensi. kita dapat melihat tingkat efisiensi Bank Syariah Mandiri (BSM), Bank Muamalat Indonesia (BMI), Bank BNI Syariah, Bank BRI Syariah dan Bank Mega Syariah (BMS) dalam menjalankan sebuah produksi yang menghasilkan output laba bersih dan pembiayaan, input modal dan biaya operasional.

Dengan pendekatan Variable return to scale (VRS) dapat dilihat tingkat efisiensi 5 BUK yaitu: Bank Rakyat Indonesia (BRI), Bank Mandiri, Bank Negara Indonesia (BNI), Bank BCA, Bank BTN dalam menjalankan sebuah operasional yang menghasilkan output laba bersih dan pembiayaan, input modal dan biaya operasional.

Tingkat efisiensi masing-masing BUK lebih dari 50\% menunjukkan nilai efisiensi secara konsisten mencapai 100\% yaitu : Bank BRI, bank BCA dan bank BTN. Sedangkan sisanya yaitu Bank Mandiri dan Bank BNI belum mencapai nilai 1 atau 100\%, ini menunjukkan bahwa sebagian BUK nilai efisiensinya masih fluktuatif.

Peningkatan efisiensi Bank Mandiri pada tahun 2014 dapat dilakukan dengan cara menetapkan target laba bersih sebesar 23.943 milyar rupiah yang saat ini sebesar 20.654 milyar rupiah atau bisa dikatakan kondisi aktual saat ini dapat mencapai target apabila laba bersih bisa terealisasi sebesar 15,924\% dari angka aktual. Peningkatan efisiensi pada tahun ini juga dapat dilakukan dengan cara menetapkan target penggunaan modal sebesar 96.588 milyar rupiah, yang saat ini telah digunakan sebesar 104.844 milyar rupiah, atau mengurangi dari nilai sekarang sebesar $7,875 \%$. Dalam rangka peningkatan efisiensi bank, biaya operasional juga harus ditekan sebesar $34,341 \%$ dari penggunaan tahun ini, atau dikurangi menjadi 32.096 milyar rupiah dari penggunaan tahun ini yang sebesar 48.883 milyar rupiah.

Peningkatan efisiensi Bank BNI pada tahun 2012 dapat dilakukan dengan cara menetapkan target laba bersih naik menjadi $23,765 \%$ atau menaikkan sebesar 8.723 milyar rupiah, dari nilai aktual saat ini sebesar 7.048 milyar rupiah. Peningkatan efisiensi bank BNI pada tahun 2012 juga dengan cara menetapkan target penggunaan modal sebesar 33.501 milyar rupiah, dari nilai aktual sebesar 43.525 milyar rupiah, atau mengurangi dari nilai aktual tahun 2012 sebesar 23,030\%. Dalam peningkatan efisiensi tahun 2012, bank BNI juga harus mengurangi biaya operasional sebesar $31,768 \%$ dari nilai aktual tahun ini, atau dikurangi menjadi 13.636 milyar rupiah dari penggunaan aktual tahun 2012 sebesar 19.985 milyar rupiah. 
Peningkatan efisiensi Bank BNI pada tahun 2013 dapat dilakukan dengan cara menetapkan target laba bersih sebesar 10.033 milyar rupiah, dari nilai aktual tahun 2013 sebesar 9.058 milyar rupiah atau bisa dikatakan kondisi aktual saat ini dapat mencapai target apabila laba bersih bisa terealisasi sebesar 10,764\%. Peningkatan efisiensi pada tahun 2013 juga dengan menetapkan target penggunaan modal sebesar 40.811 milyar rupiah, turun dari nilai aktual yang telah digunakan sebesar 47.683 milyar rupiah, atau mengurangi dari nilai aktual sebesar 14,412\%. Dalam rangka peningkatan efisiensi, biaya operasional juga harus ditekan sebesar 25,030\% dari penggunaan tahun 2013, atau dikurangi menjadi 16.467 milyar rupiah dari penggunaan aktual sebesar 21.965 milyar rupiah.

Peningkatan efisiensi Bank BNI pada tahun 2014 dapat dilakukan dengan cara menetapkan target pembiayaan $23,765 \%$ atau naik menjadi 281.639 milyar rupiah, dari nilai aktual tahun 2014 sebesar 277.622 milyar rupiah. Peningkatan efisiensi bank BNI pada tahun 2014 juga dengan cara menetapkan target penggunaan modal sebesar 48.110 milyar rupiah, dari nilai aktual 61.021 milyar rupiah, atau mengurangi dari nilai aktual tahun 2014 sebesar 21,158\%. Dalam peningkatan efisiensi tahun 2014, bank BNI juga harus mengurangi biaya operasional $25,453 \%$ dari nilai aktual, atau dikurangi menjadi 20.197 milyar rupiah dari penggunaan aktual tahun 2014 sebesar 27.093 milyar rupiah.

\section{Kesimpulan}

Dari hasil analisis yang telah dilakukan penulis, maka penulis dapat mengetahui kinerja efisiensi Bank Umum Syariah dan Bank Umum Konvensional dengan menggunakan Multi- Stage Data Envelopment Analysis, dengan pendekatan Input Oriented, sampel penelitian ini adalah 5 BUS dan 5 BUK di Indonesia, selama rentang waktu 2012-2014. Berdasarkan analisis dan pembahasan yang telah dilakukan, maka penulis dapat menyimpulkan beberapa hal mengenai penelitian ini yang di antaranya:

1. Tingkat efisiensi Bank Umum Syariah menunjukkan ada 3 bank yang relatif efisien secara CRS dan Skala pada tahun 2012, yaitu BSM, BMI dan BMS. Sedangkan untuk BNI Syariah dan BRI Syariah belum efisien, bahkan BNI Syariah menunjukkan tingkat efisiensi paling rendah, yaitu 0,535 secara CRS dan skala. Tahun 2013, sama seperti tahun sebelumnya, namun sudah menunjukkan kenaikan. Pada tahun 2014, terdapat 1 bank yang konsisten dengan nilai efisiensi optimal baik secara CRS, teknis maupun skala, yaitu BMI. Sementara BNI Syariah dan Bank BRI Syariah berhasil mencapai 
tingkat efisiensi $100 \%$ di semua bidang.. Sedangkan untuk BSM dan BMS justru mengalami penurunan tingkat efisiensi, padahal tahun sebelumnya mencapai $100 \%$, untuk BSM ini dipengaruhi berkurangnya laba bersih dan tingginya biaya operasional. Sedangkan untuk BMS dipengaruhi menurunnya tingkat pembiayaan sehingga berdampak pada penurunan laba bersih.

2. Tingkat efisiensi Bank Umum Konvensional menunjukkan ada tiga bank yang tingkat efisiensi $100 \%$ selama periode 2012-2014, yaitu: BRI, BCA dan BTN. Sedangkan Bank Mandiri mencapai nilai efisiensi 100\% pada tahun 2012dan 2013, tetapi pada tahun 2014 hanya mencapai tingkat efisiensi 92,1\%. Dan untuk BNI selama periode amatan belum mencapai tingkat efisiensi $100 \%$, mencapai tinkat efisiensi 77\% pada tahun 2012, 85,6\% pada tahun 2013 dan 78,8\% pada tahun 2014 .

3. Tingkat efisiensi BUS relatif lebih efisien selama periode 20122014, baik secara CRS maupun VRS, tetapi secara skala BUK lebih stabil dan lebih efisien dibanding BUS, karena menunjukkan tren positif di setiap tahunnya., bahkan secara teknik BUS selalu mencapai tingkat efisiensi $100 \%$, sedangkan BUK menunjukkan tingkat efisiensi yang fluktuatif. 